\title{
Hasil diagnostik Mycobacterium tuberculosis dengan pewarnaan Ziehl- Neelsen pada penderita batuk $\geq 2$ minggu di Puskesmas Ranotana, Puskesmas Wenang, dan Puskesmas Sario Manado
}

\author{
${ }^{1}$ Ireine S. Waworuntu \\ ${ }^{2}$ John Porotu'o \\ ${ }^{2}$ Olivia A. Waworuntu
}

\author{
${ }^{1}$ Kandidat Skripsi Fakultas Kedokteran Universitas Sam Ratulangi Manado \\ ${ }^{2}$ Bagian Mikrobiologi Fakultas Kedokteran Universitas Sam Ratulangi Manado \\ Email: isoeliongan@yahoo.com
}

\begin{abstract}
Tuberculosis is an infectious disease caused by Mycobacterium tuberculosis (M. tuberculosis). In Indonesia, there are about 430.000 new cases, of which 61.000 cases ended in death. This disease has many clinical varieties, therefore, a gold standard for the right and exact diagnosis is needed. The examination of sputum by using Ziehl-Neelsen staining must be more improved for public health service. This study aimed to determine the profile of Mycobacterium tuberculosis (acid-fast bacteria) among patients with coughing $\geq 2$ weeks at Ranotana, Wenang and Sario Primary Health Cares (PHCs) by using Ziehl-Neelsen staining. This was a descriptive study with a cross sectional design. Samples were obtained by using total sampling method during the period of September 2015 - December 2015. The results showed that there were 38 cases of coughing $\geq 2$ weeks as follows: 15 cases at Wenang PHC, 13 cases at Ranotana PHC, and 10 cases at Sario PHC. The examination of acid-fast bacteria from the 38 cases of three PHCs showed that 1 case $(2.7 \%)$ had acid-fast bacteria $\left({ }^{++}\right)$. Conclusion: In this study, there was only one case (2,7\%) with positive Mycobacterium tuberculosis.
\end{abstract}

Keywords: cough more than two weeks, tuberculosis, BTA

\begin{abstract}
Abstrak: Tuberkulosis adalah suatu penyakit infeksi yang disebabkan oleh Mycobacterium tuberculosis (M. tuberculosis). Indonesia memiliki sekitar 430.000 kasus baru dimana 61.000 kasus berakhir dengan kematian. Penyakit ini memiliki gejala klinis yang bervariasi sehingga perlu ditetapkan standar baku untuk menegakkan diagnosis lebih cepat dan akurat. Pemeriksaan sputum dengan pewarnaan Ziehl-Neelsen harus lebih ditingkatkan pada pelayanan kesehatan masyarakat. Penelitian ini bertujuan untuk mendapatkan gambaran Mycobacterium tuberculosis (basil tahan asam, BTA) dengan pewarnaan Ziehl-Neelsen pada pasien batuk $\geq 2$ minggu di Puskesmas Wenang, Puskesmas Ranotana, dan Puskesmas Sario Kota Manado. Jenis penelitian ini deskriptif dengan desain potong lintang. Pengambilan sampel menggunakan cara total sampling pada kurun waktu September 2015 - Desember 2015. Hasil penelitian mendapatkan 38 kasus batuk $\geq 2$ minggu yaitu 15 kasus di Puskesmas Wenang, 13 kasus di Puskesmas Ranotana dan 10 kasus di Puskesmas Sario. Pada pemeriksaan (BTA) di Puskesmas Wenang, Puskesmas Ranotana dan Puskesmas Sario didapatkan BTA (++) 2,7\% sedangkan BTA (-) 97,3\%. Simpulan: Pada penelitian ini didapatkan 1 kasus (2,7\%) Mycobacterium tuberculosis positif.
\end{abstract}

Kata kunci: batuk lebih dari dua minggu, tuberculosis, BTA

Tuberkulosis adalah suatu penyakit infeksi yang disebabkan oleh Mycobacterium tuberculosis (M. tuberculosis) dan bersifat menular. $^{1}$ Tempat masuk kuman $M$. 
tuberculosis adalah saluran pernapasan, saluran pencernaan, dan luka terbuka pada kulit. Kebanyakan infeksi tuberculosis (TB) terjadi melalui udara (airborne), yaitu melalui inhalasi droplet yang mengandung kuman - kuman basil tuberkel yang berasal dari orang yang terinfeksi. ${ }^{2}$

World Health Organization (WHO) menyatakan tuberkulosis (TB) merupakan ancaman kesehatan masyarakat global yang serius yang menyebabkan 1,5 juta kematian pada 2013 dan 9 juta orang jatuh sakit. ${ }^{3}$ Pada tahun 2014, TB membunuh 1,5 juta orang dengan laki-laki 890.000, perempuan 480.000 dan anak-anak 140.000. Berdasarkan Global Tuberculosis Report WHO (2014) terdapat 6 juta kasus baru dan diperkirakan dua pertiga (63\%) dari 9,6 juta orang telah menderita TB. ${ }^{4}$ Indonesia memiliki sekitar 430.000 kasus baru dimana 61.000 kasus berakhir dengan kematian. $^{5}$

Penyakit tuberkulosis memiliki gejala klinis yang bervariasi diawali adanya demam, batuk berdarah dan tidak ada nafsu makan sehingga menyebabkan penurunan berat badan. Penyakit ini dapat didiagnosis dengan 3 metode yaitu dengan pewarnaan Ziehl-Neelsen, pewarnaan Tan Thiam Hok dan pewarnaan fluorokrom untuk menemukan bakteri batang tahan asam Mycobacterium tuberculosis. ${ }^{2,6,7}$ Metode pewarnaan Ziehl-Neelsen merupakan pilihan metode yang cukup sederhana dan memberikan sensitivitas dan spesifisitas yang cukup tinggi. ${ }^{7}$

Penelitian ini bertujuan untuk mengetahui profil Mycobacterium tuberculosis pada pasien yang menderita batuk $\geq 2$ minggu di puskesmas kota Manado yaitu puskesmas Ranotana, puskesmas Sario, dan puskesmas Wenang. Tiga puskesmas tersebut dipilih karena menurut survei awal, kasus tuberkulosis di masing-masing puskesmas \pm 100 kasus per tahun.

\section{METODE PENELITIAN}

Jenis penelitian ini ialah deskriptif dengan desain potong lintang yang dilakukan pada bulan September-Desember
2015. Pengambilan sampel dilakukan di 3 Puskesmas Kota Manado yaitu Puskesmas Ranotana, Puskesmas Sario dan Puskesmas Wenang. Pemeriksaan sampel dilakukan di Laboratorium Mikrobiologi Fakultas Kedokteran Unsrat dengan menggunakan metode pewarnaan Ziehl-Neelsen. Setelah itu dilakukan pengolahan data.

\section{HASIL PENELITIAN}

Dari penelitian yang dilakukan dalam kurun waktu bulan November 2015 sampai Desember 2015 ditemukan 38 kasus batuk $\geq 2$ minggu yaitu 15 kasus di Puskesmas Wenang, 13 kasus di Puskesmas Ranotana dan 10 kasus di Puskesmas Sario.

Dari Tabel 1 dapat dilihat bahwa distribusi sampel penelitian berdasarkan jenis kelamin yang paling banyak ditemukan ialah laki-laki yaitu total 20 orang (52,7\%).

Tabel 1. Distribusi sampel berdasarkan jenis kelamin

\begin{tabular}{lcccc}
\hline $\begin{array}{c}\text { Jenis } \\
\text { Kelamin }\end{array}$ & Wenang & Ranotana & Sario & $\mathrm{n}$ \\
\hline Laki-laki & 10 & 8 & 2 & 20 \\
Perempuan & 5 & 5 & 8 & 18 \\
$\mathrm{n}$ & 15 & 13 & 10 & 38 \\
\hline
\end{tabular}

Tabel 2 merupakan distribusi sampel penelitian berdasarkan kelompok usia yang dominan pada pengelompokan umur 36-55 tahun dan $>55$ tahun yaitu 13 orang $(34,2 \%)$.

Tabel 2. Distribusi sampel berdasarkan kelompok usia

\begin{tabular}{cccccc}
\hline $\begin{array}{c}\text { Usia } \\
\text { (tahun) }\end{array}$ & Wenang & Ranotana Sario & $\mathrm{n}$ & $\%$ \\
\hline$<15$ & 0 & 0 & 0 & 0 & 0 \\
$15-35$ & 4 & 5 & 3 & 12 & 31,6 \\
$36-55$ & 4 & 5 & 4 & 13 & 34,2 \\
$>55$ & 7 & 3 & 3 & 13 & 34,2 \\
$\mathrm{n}$ & 15 & 13 & 10 & 38 & 100 \\
\hline
\end{tabular}

Tabel 3 memperlihatkan pasien paling banyak ditemukan pada berat badan 38$54 \mathrm{~kg}(52,7 \%)$. 
Tabel 3. Distribusi sampel berdasarkan Kelompok Berat Badan

\begin{tabular}{cccccc}
\hline $\begin{array}{c}\text { Berat badan } \\
(\mathrm{kg})\end{array}$ & \multicolumn{3}{c}{ Puskesmas } & $\mathrm{n}$ & $\%$ \\
\cline { 2 - 4 } & Wenang & Sario & Ranotana & & \\
\hline $30-37$ & 0 & 0 & 0 & 0 & 0 \\
$38-54$ & 6 & 6 & 8 & 20 & 52,7 \\
$55-70$ & 8 & 3 & 5 & 16 & 42,1 \\
$>70$ & 1 & 1 & 0 & 2 & 5,2 \\
$\mathrm{n}$ & 15 & 10 & 13 & 38 & 100 \\
\hline
\end{tabular}

Hasil distribusi Tabel 4 pada pemeriksaan BTA pasien batuk $\geq 2$ minggu di Puskesmas Ranotana ditemukan 1 sampel (7,7\%) positif dan 12 sampel (92,38\%) negatif, sedangkan di Puskesmas Wenang serta Sario tidak ditemukan sampel dengan BTA positif.

Tabel 4. Hasil Pemeriksaan BTA di Puskesmas Kota Manado

\begin{tabular}{lcccc}
\hline \multirow{2}{*}{ Puskesmas } & \multicolumn{2}{c}{ BTA (+) } & \multicolumn{2}{c}{ BTA (-) } \\
\cline { 2 - 5 } & $\mathrm{n}$ & $\%$ & $\mathrm{n}$ & $\%$ \\
\hline Ranotana & 1 & 7,7 & 12 & 92,3 \\
Wenang & 0 & 0 & 15 & 100 \\
Sario & 0 & 0 & 10 & 100 \\
Total & 1 & 7,7 & 37 & 92,3 \\
\hline
\end{tabular}

\section{BAHASAN}

Penelitian ini dilakukan pada pasien yang batuk $\geq 2$ minggu di Puskesmas Wenang, Puskesmas Sario, dan Puskesmas Ranotana pada periode pengambilan sampel bulan November 2015 sampai Desember 2015 dan didapatkan 38 sampel.

Berdasarkan distribusi kasus menurut jenis kelamin pada pasien batuk $\geq 2$ minggu ditemukan yang tertinggi terjadi pada lakilaki (52,7\%) dibandingkan perempuan (47,3\%). Wen et al. ${ }^{8}$ menyatakan bahwa dominasi gender yang terpapar Mycobacterium tuberculosis ialah laki-laki (52,4\%) dibandingkan perempuan (47,6\%).

Perbandingan ini juga mendekati hasil penelitian yang dilakukan oleh Munir et al. ${ }^{9}$ yang melaporkan pasien laki-laki (52,5\%) lebih tinggi dibandingkan perempuan (47,5\%). Jurnal Tuberkulosis Indonesia tahun 2012 menyatakan bahwa infeksi TB memang cenderung lebih sering diderita oleh laki-laki dibandingkan perempuan. Hal ini antara lain disebabkan karena faktor kebiasaan merokok yang dapat meningkatkan risiko infeksi TB paru sebanyak 2,2 kali. $^{9}$

Distribusi kasus berdasarkan kelompok usia pasien batuk $\geq 2$ minggu ditemukan yang tertinggi pada usia 36 tahun sampai usia >55 tahun. Hasil penelitian ini sesuai dengan Jurnal Kesehatan Masyarakat yang menyatakan sebagian besar penderita TB atau sebesar 75\% terdapat pada usia produktif antara 1549 tahun. ${ }^{1}$ Laporan dari Sub Direktorat TB Depkes RI tahun 2006 menyatakan bahwa infeksi TB sebagian besar diderita oleh masyarakat yang berada dalam usia produktif (15-55 tahun) dengan tingkat sosial ekonomi yang rendah. ${ }^{9}$

Hasil distribusi berdasarkan kelompok berat badan yang paling banyak ditemukan yaitu 38-54kg (52,7\%). Hal ini sesuai dengan hasil penelitian Bhargaval et al. ${ }^{10}$ yang melaporkan bahwa berat badan 3442kg merupakan berat badan yang dominan pada penderita TB. Berbeda dengan penelitian yang dilakukan oleh Munir et al. ${ }^{9}$ yang menyimpulkan bahwa berat badan terbanyak ialah >50 kg (37,6\%). Hal ini mungkin disebabkan oleh status gizi seseorang yang memengaruhi daya tahan tubuh terhadap penyakit TB. ${ }^{11}$

Dari distribusi hasil pemeriksaan BTA pada 3 puskesmas didapatkan BTA (+) 2,7\% sedangkan BTA (-) 97,3\%. Hasil penelitian ini berbanding terbalik dengan laporan Global Tuberculosis Report 2014 yang menyatakan $82 \%$ perkiraan insiden kasus TB di seluruh dunia. ${ }^{12}$ Sama halnya 
menurut Tuberculosis Epidemiology in the United State menyatakan bahwa kasus TB menurun lebih dari 10\% dari tahun 2008 2009 sehingga pada tahun 2011 dilaporkan total kasus TB 10.528 yang telah mengalami penurunan $5,8 \%$ dari tahun $2010 .{ }^{13}$

Karena masih banyaknya kasus TB, maka WHO membuat suatu program "The END TB Strategy” dengan harapan bahwa dunia bisa terbebas dari penyakit TB. Target program ini ialah mengakhiri wabah penyakit TB pada akhir tahun $2035 .^{14}$

Di Indonesia sendiri, program Stop TB telah dimulai pada tahun 1995 dengan strategi DOTS. Program pengendalian TB di Indonesia telah terlihat keberhasilannya dengan menurunnya jumlah penderita di peringkat dunia, namun untuk mencapai target MDG's pada tahun 2015 diperlukan penguatan program penanggulangan TB dengan strategi Directly Observed Treatment Shortcourse (DOTS), di mana salah satu komponennya ialah pemeriksaan mikroskopik TB yang bermutu. ${ }^{15}$ Pemeriksaan mikroskopis TB dengan metode pewarnaan Ziehl-Neelsen tetap menjadi alat diagnostik utama TB di Indonesia. $^{15,16}$ Sumber daya manusia dan fasilitas di laboratorium mikrobiologi perlu ditingkatkan untuk mencapai hasil yang baik.

\section{SIMPULAN}

Berdasarkan hasil penelitian pada 3 puskesmas di Kota Manado dengan 38 kasus batuk $\geq 2$ minggu selama bulan November 2015 sampai Desember 2015, dapat disimpulkan bahwa kasus yang terbanyak ialah jenis kelamin laki-laki, usia 36-55 tahun dan >55 tahun, dan berat badan $38-54 \mathrm{~kg}$.

Pada pemeriksaan BTA pada kasus batuk $\geq 2$ minggu ditemukan 1 sampel (7,7\%) positif dari 13 sampel di Puskesmas Ranotana sedangkan di Puskesmas Wenang serta Sario tidak ditemukan BTA positif.

\section{SARAN}

1. Diharapkan peneliti selanjutnya dapat menambah beberapa variabel dalam penelitian untuk dijadikan bahan referensi dan perbandingan dengan penelitian sebelumnya.

2. Tenaga kesehatan di Puskesmas harus meningkatkan kemampuan dalam menegakkan diagnosis TBC sesuai dengan standar prosedur yang berlaku.

\section{DAFTAR PUSTAKA}

1. Suharyo. Determinasi Penyakit Tuberkulosis di daerah Pedesaan. Jurnal Kesehatan Masyarakat. 2013;1:85-91.

2. Prince SA, Wilson LM. Tuberkulosis Paruparu. In: Wijaya C, editor. Patofisiologi Konsep Klinis Prosesproses Penyakit (4th ed). Jakarta: EGC, 1995.

3. Digital health for the End TB Strategy: An Agenda for Action. Available from: http://www.who.int/tb/publications/di gitalhealth-TB-agenda/en/

4. Global tuberculosis report 2015. Available from:

http://www.who.int/tb/publications/gl obal_report/en/

5. Rumanga WR, Rombot DV, Palandeng HMF. Gambaran Autopsi Verbal Pasien yang Meninggal karena Tuberkulosis di Kota Manado. Jurnal Kedokteran Komunitas dan Tropik. 2015;3(1):48-54.

6. Noer HMS. Buku Ajar Ilmu Penyakit Dalam (3rd ed). Jakarta: Balai Penerbitan FKUI, 1996.

7. Karuniawati A, Risdiyani E, Nilawati S, Prawoto, Rosana Y, Alisyahbana B, et al. Perbandingan Tan Thiam Hok, Ziehl Neelsen dan Fluorokrom sebagai Metode Pewarnaan Basil Tahan Asam untuk Pemeriksaan Mikroskopik Sputum. Kesehatan. 2005;9:29-33.

8. Wen YT, Huang SF, Lee MC, Lin, Lee CY, Feng JY, et al. Gender Disparities in Latent Tuberculosis Infection in High-Risk Individuals: A Cross-Sectional Study. PLOS One. 2014;9:1-8.

9. Munir SM, Nawas A, Soetoyo DK. Pengamatan Pasien Tuberkulosis Paru dengan Multidrug Resistant (TBMDR) di Poliklinik Paru RSUP Persahabatan. Respirasi Indonesia. 
2010;30:92-104.

10. Bhargava1 A, Chatterjee $M$, Jain $Y$, Chatterjee B, Kataria A, Bhargava M, et al. Nutritional Status of Adult Patients with Pulmonary Tuberculosis in Rural Central India and Its Association with Mortality. PLOS One. 2013;8:1-11.

11. Manalu HSP. Faktor-faktor yang mempengaruhi Kejadian TB Paru dan Upaya Penanggulangannya. Jurnal Ekologi Kesehatan. 2010;9(4):13406.

12. Global tuberculosis report 2014. Available from:

http://apps.who.int/iris/bitstream/106 65/137094/1/9789241564809_eng.pd $\mathrm{f}$

13. Overview of Tuberculosis Epidemiology in the United States. Available at: http://www.cdc.gov/tb/education/core curr/pdf/chapter1.pdf

14. WHO The End TB Strategy 2015. Available at: http://www.who.int/tb/post2015_TBst rategy.pdf

15. Stop TB - Strategi Nasional Pengendalian TB di Indonesia, KEMENKES RI 2011. Available from: http://www.searo.who.int/indonesia/t opics/tb/stranas_tb-2010-2014.pdf

16. Standar Prosedur Operasional Pemeriksaan Mikroskopis TB, KEMENKES RI 2012. Available from: http://www.tbindonesia.or.id/opendir/ Media\%20Kit/Pedoman\%20Lab/Boo klet\%20SPO\%20Mikroskopis\%20TB .pdf. 